DOI: $10.17516 / 1997-1370-0642$

УДК $17.01 ; 17.02$

\title{
Moral Philosophy and Ethics: The Demarcation Line
}

\author{
Abdusalam A. Guseynov* \\ Institute of Philosophy, Russian Academy of Sciences \\ Moscow, Russian Federation
}

Received 02.03.2020, received in revised form 04.08.2020, accepted 11.08.2020

\begin{abstract}
The paper proposes an idea that moral philosophy and ethical theory are congruent with each other in their subject, but differ in their methods: the first one grasps a human act from the inside in its primary moral genesis, while the second one studies morality in its outward objectified forms. The author bases this view on his own interpretation of Mikhail Bakhtin's moral philosophy, presented in his early works «Toward a Philosophy of the Act and Author» and «Author and Hero in Aesthetic Activity». The opposite sides of an act, which is rooted in a living individual with one side and in culture with another one, acquire the inner character and entirety through personal moral responsibility.
\end{abstract}

Keywords: moral philosophy, ethics, act, responsibility, Mikhail Bakhtin.

Research area: philosophy.

Citation: Guseynov, V.K. (2020). Moral philosophy and ethics: the demarcation line. J. Sib. Fed. Univ. Humanit. Soc. Sci., 13(8), 1289-1297. DOI: 10.17516/1997-1370-0642.

The first sentence which ethics begins from, a kind of a key that unlocks its door, is as follows: ethics is a doctrine of morality. There is a misconception in the statement that "ethics" and "morality" are different concepts. Since the word "moral" is the Latin translation of the Greek word "ethics", the original definition should be as follows: ethics is the doctrine of ethical. Indeed, having called some of his works ethics, Aristotle denoted the very subject area he studied in these works: something related to people's ethos. In much the same way as the science of physics studies physics and the doctrine of the soul studies the soul, ethics studies ethics. The word "moral" appears later. Cicero translated the Aristotele's term into Latin and called ethics "moral philosophy."

There is a historically developed tradition of combining Greek and Latin words in one meaningful sentence: ethics is the science of morality, as if they had different semantic loads. This is how the fate of these words developed in the modern Russian and other European languages. This mixture of languages,

(C) Siberian Federal University. All rights reserved

* Corresponding author E-mail address: guseynovck@mail.ru ORCID: 0000-0002-0817-7869

Translation of an article published in Russian: Guseynov, A.A. (2019). Nravstvennaya filosofiya i etika [Moral Philosophy and Ethics]. In Eticheskaia mysl' [Ethical Thought], 2, 5-16. 
which makes it possible to call the science (ethics) which studies a certain subject area, and this subject area (morality) itself differently, cannot but affect understanding of the essence of the matter. The existence of different terms (words) to denote the same concept can become a factor that provokes differences in meanings. In addition, there was another extra point here.

Cicero not only specified a new subject area with the Latin word "moral", but he also pointed out that it was a field of philosophy and called ethics moral philosophy. It is obvious that Aristotle also considered ethics to be a part of philosophy, however, there was no such indication of the generic trait in the term itself. With his translation, Cicero enriched the concept of ethics, as if the father's name was added to the son's given name. As a result, "ethics" received the second name "moral philosophy." Although both terms - "ethics" and "moral philosophy" - express the same concept, and are, basically, identical, having appeared as a result of a simple translation, nevertheless, over time, neither of them was considered as redundant. There is an obvious difference between them and, although they mean the same subject, nevertheless, the term moral philosophy focuses on the generic trait, and ethics - on the species difference.

On the one hand, ethics deals with various morals (norms, actions, assessments, etc.) that people actually practice in society, and on the other hand, it considers people's behaviour from the point of view of what they should do to make their life perfect. It is one thing when people build their relationships in accordance with their interests, circumstances, opportunities and consolidate them in a shared social experience, another thing is when they are guided by what is dictated to them by true philosophical reason. This divergence between the objective external logic of morality itself and its philosophical normative programme, the divergence known to us as the is-ought problem, is the internal tension of ethics, which it has dealt with in various forms throughout its history and which has not been overcome until now ${ }^{1}$. Let us go further and consider moral phi-

I would like to draw your attention to the discussion which took place 10 years ago. It was about specific features, due losophy and ethics not as two different levels (aspects) of the same discipline, but as two different disciplines. This understanding underlies the philosophy of the act by M.M. Bakhtin, who believes that moral philosophy and ethics deal with the same subject - morality, but differ in methods: moral philosophy belongs to the domain of philosophy, and ethics - to the domain of science, and is a kind of theoritism as any other science ${ }^{2}$.

$* * *$

Ethics emerged and historically developed as an integral part (aspect) of philosophy; it is still considered as a synonym for practical philosophy, which is seen as philosophy in its application to the field of human freedom. To the extent that human freedom is identical to person's morality, practical philosophy can be called moral philosophy and philosophy of morality. What is morality or what refers to morality and is the general subject of our science?

With all the variety of opinions on this issue in special literature and among ordinary people who practice morality and have their own ideas about it, although they do not theorise about it, a number of its common indisputable features can be distinguished. It is a category of practice and activity, which constitutes its immanent property of dividing the entire subject diversity of the world into two large classes: good and evil. This division results from the purposeful

to which ethics is a philosophical science. It, in particular, contains the point of view that to the extent that ethics offers its own moral normative programme, it can be substantiated in the context of philosophy in general: it is rooted in metaphysics and ends in non-ethical sphere. Ethically ought grows from the depths of philosophy itself (Ref.: Guseinov, A.A., Razin, A.V., Brodskii, A.I., Lobovikov, V.O., Apressyan, R.G., Gelfond, M.L. (2012). "Filosofskaia etika i ee perspektivy v sovremennom mire (Kruglyi stol k 10-letiiu ezhegodnika "Eticheskaia mysl"')" [Philosophical Ethics and Its Perspectives in Modern World: Round-Table to the 10th Anniversary of the Yearbook, Eticheskaia Mysl (Ethical Thought)]. In Eticheskaia mysl' [Ethical Thought], 12, 5-33).

2 Ref.: Bakhtin, M.M. (2003). "K filosofii postupka" [Toward a Philosophy of The Act]. In Bakhtin M.M. Sobranie sochinenii $v 7$ tomakh [Collected Works, 7 Volumes], Vol. 1, Moscow, 7-68; Bakhtin, M.M. (2003). "Avtor i geroi v esteticheskoi deiatel'nosti' [Author and Hero in Aesthetic Activity]. In Bakhtin, M.M. Sobranie sochinenii [Collected Works], Vol. 1. Moscow, 69-263. 
nature of human activity, from the fact that its causality is set as the purpose which an acting individual is guided by. It does not refer to what exactly is good and evil and, accordingly, a positive or negative purpose of activity, but to the very ability and necessity to build your activity along these axes. It is consolidated in an individual by the mechanisms of duty and conscience, which give him/her a special dignity of a moral subject. The very concepts of good and evil, conscience, duty, dignity, as well as the behavioural schemes behind them, are not called by anyone into question (even by those who consider them fake) as the markers that enable the identification of the space of morality. Morality, therefore, denotes that special aspect of human practice, which consists in the fact that when acting an individual proceeds from him/herself, that he/she cannot but orient him/ herself in the coordinates of good and evil and cannot but bear the traces of how an individual does it him/herself.

Whoever has the choice has the torment (wer die Wahl hat, hat die Qual), says a German proverb. People have noticed, and at the level of everyday consciousness recorded, that their desire for good often turns into evil, the soul is tormented by the stings of remorse when, it would seem, it should jump for joy, the duty becomes a heavy burden. It turned out that being rooted in the will of an acting subject, morality is also associated with truth, and has its own objective parameters. By the logic of being itself, a person is faced with the problem of how to orient him/herself in the world and, above all, among people, through relations which he/ she only deals with the world, so that his/her desire for good does not turn into evil? What rules and moral law does an individual need to follow for this? The pinnacle, to which moral practice has risen in search of an answer to this question, is a rule that is represented in all world (and not only world) religions and cultures and which, in our market era, is called the Golden Rule: (do not) treat others in ways that you would (not) like to be treated.

To be the cause of one's own judgments and actions, connecting a person to other people and creating their own human world, means to be moral. Briefly, morality could be defined as a kind of an individually responsible way of an individual's existence in the world of people, which gives a person a new concreteness, peculiar only to him/her. It is a specific type of an individual's connection with other people, the essence of which is that an individual considers the world of people, which he/she lives in, as his/her world, as if it were created by his/her actions. According to this disposition, an individual divides his/ her own actions into two large and very general classes - into good (virtuous) and evil (vicious), denoting, respectively, their positivity and negativity: what an individual should do and what he/she should not do when building his/her own relationships with others. Everything that an individual does, and all the forms of his/her conscious activity fit into these rubrics, and due to this an individual's existence acquires a moral nature. An individual cannot but strive for good, for good is what he/she strives for, and in the same way an individual cannot but avoid evil, for evil is what he/she avoids. It is arguable that there has not been such evil in the world that would not have pretended to be good.

$* * *$

Moral acts are not a specific class of acts, but a specific perspective of their consideration, a specific dimension of everything that an individual does consciously, emphasising their reference to this individual as their cause, as the authority that is responsible for them. In the strict sense of the word, moral acts do not exist as independent objects; in this sense, the Stoics, who distinguished a correct, equal to itself effort accompanying the vital activity of an individual from this very activity in its material (empirical) content, or Kant, who doubted the possibility of acting for the sake of duty, expressed a real singularity of the inclusion of morality into human existence. The concept of a moral act is, in a sense, a conditional expression: in fact, we are talking about a specific aspect of any act, indicating its personal origin, and answering the question of who committed it. It is necessary to distinguish the genesis of an act, with a particular living individual behind it, from its objective 
content: in one case it is about who committed an act, who brought it into the world, and in the other one - about its content and how it fits into the world. This difference was perfectly expressed by Bakhtin, saying that an act, like an ancient two-faced god of entrances and exits, "looks in two opposite directions: it looks at the objective unity of a domain of culture and at the never-repeatable uniqueness of actually lived and experienced life." ${ }^{3}$ It is possible to conduct such a mental experiment and mentally subtract (take out of the brackets) from a person's relationships to other people all their diverse objective content and everything connected with an issue in connection with what they are built and by virtue of which they acquire concreteness, becoming sibling, business, friendly, romantic, personal, official, financial, territorial, civil, political, scientific, criminal, and so on and so forth. The question, what will remain after such a subtraction, arises. Nothing but the most abstract reference to others. It is this pure idea of connectedness with others that is the moral attitude that precedes all possible concrete relationships with them, which, if we use the metaphor of weaving art, constitutes the basis on which the knots of individual actions are tied and the drawing of life is embroidered.

The key (central) issue of morality is as follows: how to harmonise the subjectively given moral orientation of actions with their objective content to endow it with a socially significant meaning? How can an individual cope with the responsibility that lies on him/ her (imposed by his/her being) to behave in such a way that his/her actions were continued in the actions of others? What needs to be done so that an individual's desire for happiness does not turn into a great misfortune, as it happened with King Croesus, so that the javelin thrown by the athlete during the competition does not kill Epitimus of Pharsalus, as happened in the case, which, according to Plutarch, was discussed all day by Peri-

\footnotetext{
3 Bakhtin, M.M. (2003). K Philosophii postupka [Toward a Philosophy of the Act], 7. Bakhtin, M.M. (1993). Toward a Philosophy of the Act. Ed. Vadim Liapunov and Michael Holquist. Trans. Vadim Liapunov. Austin: University of Texas Press. P. 2.
}

cles with Protagoras, so that the philosophers who talk about all this would not be expelled from the town like Protagoras, not executed like Socrates, and not sold into slavery like Plato? The problematic situation created by the emergence of morality became one of the main reasons that laid the foundation for ethics as a specific field of theory, and for the key themes, that determined the direction of its research efforts. If we try to give a general consideration to the development of European ethics, how it has developed since antiquity, it is possible to single out its undoubted prevailing tendencies in the issue of our interest. In all the originality of individual teachings, the difference and even polarity of the established traditions, and their internal polemics, ethics has been developing as a theoretical discipline, it considered the world of human acts as some givenness, tried to generalise it in stable regular connections and find ways to bring human aspirations in line with these regularities. Ethics tried to find a universally valid truth of practical reason and, in most cases, it formulated a programme of proper (correct, worthy) behaviour itself. In this sense, it was on the side of society, on the side of truth, and was as a teacher for living individuals, acting, as they say, at their own peril and risk, bearing the burden of life responsibility. It pretended to think for them and tell them what they should do. Although many philosophers endowed their ethical theories with a personal morally binding meaning and built their lives according to their own teachings, - their individual experience, nevertheless, acquired the value of a theoretically significant argument. Diogenes lived in a barrel, but let us not forget that this barrel was in a crowded city square and, in this sense, he practiced as a theorist, giving his life the value of an argument.

$* * *$

From an extremely general retrospective position of the development of ethics, it should be noted that, in general, at all stages and in all varieties, it understood morality as practical relationships between a person (an individual) and other people. This gave and gives it an objective unity. In the concrete 
interpretation of these relationships, there were, of course, quite important differences. In particular, it is possible to distinguish two tendencies that were neither clearly identified nor clearly formulated, but, nevertheless, were always represented in real ethical teachings to the extent the latter were a part of philosophy. They can be conditionally designated as philosophical-individualising (personalistic) and scientific-generalising, which (but again) very conditionally corresponds to the division into individual ethics and social ethics. However, these differences, like many others ones, for instance, the difference between the ethics of happiness and the ethics of duty, remained within the framework of the general view of ethics as a theory of morality and the general desire to give it a universally valid evidence-based interpretation. Morality was considered as something given, objectified, subject to comprehension and generalisation like any other subject. If it concerned a moral act, it became the subject of ethics in the aspects that could be fixed and described motives and results. If it concerned norms, the issue of their general nature and binding force in relation to individuals was at the foreground. Individuals, the relationships between whom morality was supposed to cement, were considered as units, equal in their striving for good, and their relationships were an independent good. Ethics tapped into thinking about the problem which individuals solved in the real experience of living together, in particular, how to combine and unite their own, each time individual aspirations for the good with the binding common good. It claimed to be a reputable neutral authority in moral issues to teach people the correct strategy of social behaviour, acting on behalf of a virtuous person, a wiseman, an ideal kingdom, or a safe and harmonious society.

Ethics faced a number of dilemmas which indicated that moral problems could not be solved following scientific (theoretical) interpretation it had chosen. Let us recall only a few of them.

- The view of morality as a givenness presupposed that it must be inscribed in the causality of the world, it should be given a certain basis for its motives and norms that would sanction their legitimacy and explain their binding character. But this contradicted the original intention that proceeded from the inherent value of morality, excluding the very idea of the justification of morality.

- According to Kant, the main question of morality is: "What should I do?" Not only according to Kant, but also in essence, since this is exactly what interests a person in morality. In morality an individual wants to speak on his own behalf, in the first person. But both in the past and in the present, ethics answers another question: "What should you do?", "What should a person do in general to comply with his/her purpose, the common good, etc.?" It dealt with the abstraction of a person, but not with a living and acting individual.

- The driving force of morality is practical reason. While formulating general canons of behaviour, whether they are norms, virtues, or evaluative criteria, ethics replaces it with theoretical reason, talking about what is the best, while it is expected to answer the question of how to choose the best.

- The problem of free will should be necessarily added to the dead ends of ethics, which is oriented toward the explanation what it is and proving its existence, although it is obvious that the proof of the existence of free will would mean that it actually does not exist.

Ethics objectifies morality, looks at it outwardly, from a distance, from the point of view of the general, while it is fundamentally subjective and personal; it regards the moral problem as scientific, while, in fact, it is existential. It deals with the traces of a meteorite and its pieces scattered on the ground, but not with the mesmerising fiery stream flying from above. An ethical scientist speaks of morality, taking himself out of brackets, as if with this supposedly neutral position he himself does not express a certain moral position of people and institutions who want to deal with other people's problems instead of dealing with their own. The history of ethics, to the extent it naturally came to the present state, leads us to the idea that for an adequate understanding of morality it is necessary to change the method, and from reasoning in the third person shift to 
talking in the first person, from the knowledge of morality shift to its self-consciousness, and from the science of morality shift to the philosophy of morality.

\section{$* * *$}

To understand morality as a matter of philosophy, as practical reason, it is necessary to understand philosophy itself as a moral position, as the point of view of practical reason. Nobody argues that as a way of cognition of the world, philosophy also considers issues of the meaning of human life. The question is how these aspects relate to each other: what is primary - knowledge about the world or our position in life in relation to it. The three-part division of philosophy into physics, logic and ethics is well-known, and it exhaustively sets its general structure. Ethics in philosophy was considered as the last, final, the third step of the ladder, Descartes placed it on the branches of a tree, the root of which is metaphysics, and the trunk stands for physics. In what sense is ethics the third step: in the sense that we reach it only after we have passed the first two, such as, for instance, a dessert that we receive as a third course? It seems that, as a rule, the place of ethics in philosophy is understood in this way, this is the way it is taught in our courses, following ontology and epistemology, and ethics as a specific science of morality arose from this understanding; hence the idea of the value neutrality of knowledge. But ethics can also be understood as the third and last part in the sense of the goal, which, being finite in reality, is initial in activity and indicates the path one must go to achieve it. In order that ethics remained the third part of philosophy, its way out into practice, philosophy itself must be a kind of practice, an ethical project. Such a view can be found in the Bakhtin's philosophy of the act, or, to put it more carefully, in how his philosophy of the act can be understood.

It should be especially emphasised that the Bakhtin's philosophy of the act is not just a doctrine of an act, it claims to be the first philosophy. An act is a category of practical reason, not one of the manifestations (characteristics) of a person, but a way of being, inherent in him/her. The world and his/her own being in it are given to a man as an opportunity, which he/she transfers into reality through his/her life. Being is not given to a person but something-to-be-accomplished. A person has no alibi in Being, he/she is in a sympathetic attitude towards it and has to do something with it, has to give it certainty, has to act, cannot but act, "has to ought", since this is the way of a person's life. More specifically: a) everything in a person is an act: and a thought, and a feeling, and a deed, any manifestation of his/her activity - a conscious life, taken at its every given moment; b) an act is directed to the future, it is something new that a person brings into the world and what he/she does with the world; c) an act is individual, one-and-the-only, it is committed by a given specific individual, from the place that is occupied only by him/ her, a specific space and time and, therefore, no one else can commit it; d) a living individual, not a subject, not a rational being, not a representative of a dynasty, etc. is at the origins of an act, this living individual is endowed with consciousness and with his/her own name in the undivided whole of all his/her forces, due to which he/she lives, he/she is not the one who commits an act, but the one who comes into being in an act, he/she does not exist before an act itself, as well as an act itself does not exist without him/her; e) an act is the unity of an individual (life) and the world (culture), it reflects itself in two directions - in the acting (doing) individual, who is responsible for the very fact of the act and its being in the world, and in the world that determines the content of the act, gives it the meaning; an act exists in integrity and in the unity of both aspects; f) the unity of an act is not achieved when moving from the content of an act to an act as a fact, since the objective necessity of an act does not entail its subjective necessity (using the concept of love it is impossible to explain why Desdemona fell in love with Othello), but the fact of an act necessarily includes its content as a constituent moment and is primary in relation to it (having fallen in love with Othello, Desdemona enters the space of love and using the available experience enriches it herself).

Unity and integrity of an act is achieved by its responsibility. Not the responsibility that 
we know from dictionaries and textbooks when someone is responsible to someone (a citizen to the law, a son to a father, a husband to his wife, a moral individual to public opinion and his conscience, deputies to voters, etc.), although it is also included in the content of an act as one of the moments, but a specific responsibility that is immanent in an act itself and is its human core. We act while living, and we live while acting. An act is committed finally, irrevocably, it is a moment of life itself, in much the same way as by eating we support ourselves physiologically, so, by acting we live a human (conscious) life. By acting, we put our human dignity on the line, and is there a higher degree of responsibility than the dignity of life, which we could be accountable to?! In accordance with the two-part nature of an act, responsibility is also two-sided: moral responsibility for the fact of an act and special responsibility for the content of an act. The correlation between them is the same as between the fact (Being) of an act and its content: special responsibility is a constituent moment of moral responsibility. As a matter of fact, when deciding to commit an act, an individual only specialises his/ her responsibility and takes responsibility for its content, one thing does not exist without the other: this means that an individual is responsible for everything he/she does, for all thoughts, judgments, feelings, actions, views and his/her life - on the solitary and irrevocable ground that these are his/her thoughts, his/her judgments, his/her feelings, his/her actions, his/her views, and his/her life. Everything that an individual can call "mine", and this can and must be said about everything what he/she is connected with by his/her actions, what is included in the sphere of an individual's moral responsibility, and not by his/her choice and desire, but by the necessity of existence, due to the unconditional fact that he/she has no alibi in Being.

$* * *$

Although acts do not have common definitions and each of them is independent, they all have common architectonics, they all have the same structure and are built according to the same relationship scheme: I and the other. In Bakhtin's moral universe, the centre, the sun from which all rays emanate is I. Others are like planets; they shine with the reflected light of the sun. The other is not the same as I, he/she is exactly the other, moreover, he/she is not I. They are fundamentally different, they cannot be equalised, since this would require a third one, and this would destroy the space of an act, and I and the other would turn from the only ones into singular; they are also not mutual, since reciprocity requires a mediating norm. Their relationships are unidirectional (from I to the other) and based on the centre. "The relationship of 'I and the other' is absolutely irreversible and given once and for all." "These basic moments are I -for-myself, the other-forme, and I-for-the-other. All the values of actual life and culture are arranged around the basic architectonic points of the actual world of the performed act or deed..."

An act is singular, but this does not mean that an actor is lonely. Quite the opposite, since an act that is with one side rooted in an individual, in "I" (in "I" not as a synonym for self-consciousness, not as a rational subject, but in "I" as an actual living and acting individual), and with another one in the world of other people. Thus, it is initially and existentially connected with other people. According to Bakhtin, two voices are the minimum of life and the minimum of Being. The social nature of man is not a secondary result of individuals' activity, no matter how this activity is interpreted, but a primary fact, a specific feature of his/her mode of existence. The connection of I and the other (others) is not the result of ethical decisions, but the initial moral something-to-be-achieved of individuals' being, which, in fact, do not exist beyond this yet-to-be-achieved (not to be confused with the sociological problem of communication in individualised societies of

\footnotetext{
4 Bakhtin, M.M. (2003). Avtor i geroi v esteticheskoi deiatel'nosti [Author and Hero in Aesthetic Activity], 130. Bakhtin, M.M. (1990). "Author and Hero in Aesthetic Activity". In Art and Answerability: Early Philosophical Essays. Ed. Michael Holquist, Vadim Liapunov. Austin, University of Texas Press. P. 52.

5 Bakhtin, M.M. (2003). K Philosophii postupka [Toward a Philosophy of the Act], 49. Bakhtin, M.M. (1993). Toward a Philosophy of the Act. Ed. Vadim Liapunov and Michael Holquist. Trans. Vadim Liapunov. Austin: University of Texas Press. P. 54.
} 
the Modern era). The nature of this connection is determined by the structure of an act: more specifically, I is in the centre, it is the centre of the event of being, of the whole new configuration of the world which is created by an act, the other is secondary and derivative, connected with I due to the content, the meaning of an act. Although the central point in the lines "I and the other" is I-for-myself, this in no way should be interpreted as selfishness. It only means that I live from myself, as the centre that organises the eventual definiteness of Being. The entirety of life from myself is realised in a position that Bakhtin calls an absolute self-exclusion.

Since an act (every act!) is unique and one-and-the-only, and this is its basic characteristic, it cannot be generalised, interpreted in a concept, and made the subject of theory and scientific generalisation: all these procedures eliminate individuals in their uniqueness. The foregoing does not mean that they cannot be talked about, it is possible, but not in a descriptive, generalising impersonal language, but in a situational language, taken in all the diversity of conceptual, figurative and expressive, as well as emotional and volitional means.

$* * *$

Thus, philosophy is a focus on an act from the inside, the position of an actor as if an actor was a philosopher himself, it considers an act in its personally expressed genesis and uniqueness, as an individually responsible way of being in the world, which is determined, not chosen, but is precisely determined, rigidly and unambiguously set by the ontological status of a person. The philosophy of the act affirms the active nature of human Being, the primacy of practical reason over the theoretical one, and acts as the first philosophy, which, thereby, turns out to be moral. Moral philosophy pro- ceeds from the fact that the very being of a person, due to his/her individually expressed uniqueness and singularity at all moments of life, is responsible, and cannot but be such. It differs from ethics, which is guided by the canons of scientific rationality, deals with already committed, objectified actions, looks at them from the outside, through the prism of the concepts of good and evil, and expresses the point of view of public morality. As for the relationship of I-the other that is the core of morality, ethics declares itself as a third one, claiming for the role of an objective arbitrator between them. This, the fact that ethics introduces a third one into the relationship between "I and the other" ("correct point of view", "common good", "universal norm", etc.), and moral philosophy does not allow any gap between "I and the other" since "I" does not have alibi in Being - the gap that gives an opportunity to tear away from "the other", to look at him/her from the outside, - this is exactly what distinguishes moral philosophy from ethical theory. The first one, moral philosophy, speaks in the first person about what I should do, what I should ought, it affirms me in my spontaneous vitality, the second one, ethical theory, says what we should do in accordance with general concepts and the canons that are dictated by science in accordance with its objective theory; the first one looks at the world and culture from within the necessity of my only life, the second one looks at my life outwardly, from what someone thinks is right for me; the first one puts me on the line and reveals Being as personal responsibility, the second one teaches how to be rational and make the right choice; the first one puts me in the centre, forcing me to live from myself, the second one teaches me to equalise myself with others and to measure my own good with the good of others.

\section{References}

Bakhtin, M.M. (1990). "Author and Hero in Aesthetic Activity". In Art and Answerability: Early Philosophical Essays. Ed. Michael Holquist, Vadim Liapunov. Austin, University of Texas Press. P. 4-256.

Bakhtin, M.M. (1993). Toward a Philosophy of the Act. Ed. Vadim Liapunov and Michael Holquist. Trans. Vadim Liapunov. Austin: University of Texas Press. 133 p.

Bakhtin, M.M. (2003). K filosofii postupka [Toward a Philosophy of the Act]. In Sobranie sochinenii v 7 tomakh [Collected Works, 7 Volumes], Vol. 1. Moscow, Iazyki slavianskoi kul'tury Publ., 7-68. 
Bakhtin, M.M. (2003). Avtor i geroi v esteticheskoi deiatel'nosti [Author and Hero in Aesthetic Activity]. In Sobranie sochinenii v 7 tomakh [Collected Works, 7 Volumes], Vol. 1. Moscow, Iazyki slavianskoi kul'tury Publ., 69-263.

Guseynov, A.A., Razin, A.V., Brodskii, A.I., Lobovikov, V.O., Apressyan, R.G., Gelfond, M.L. (2012). "Filosofskaia etika i ee perspektivy v sovremennom mire (Kruglyi stol k 10-letiiu ezhegodnika "Eticheskaia mysl"')" [Philosophical Ethics and Its Perspectives in Modern World: Round-Table To The 10th Anniversary of the Yearbook, Eticheskaia Mysl (Ethical Thought)]. In Eticheskaia mysl' [Ethical Thought], $12,5-71$.

\title{
Нравственная философия и этика: линия разграничения
}

\section{A.А. Гусейнов}

Институт философии РАН

Российская Федерация, Москва

\begin{abstract}
Аннотация. В докладе академика А. А. Гусейнова высказывается идея, согласно которой нравственная философия и этическая теория совпадают между собой предметом, но отличаются методами: первая схватывает поступок изнутри в его первоначальном моральном генезисе, вторая исследует мораль в ее внешних объективированных формах. Автор опирается на собственную интерпретацию нравственной философии М.М. Бахтина, изложенной в его ранних произведениях «К философии поступка» и «Автор и герой в эстетической деятельности». Противоположные стороны поступка, уходящего одним концом в живого индивида, и другим - в культуру, обретают внутренний план и целостность на базе персональной нравственной ответственности.
\end{abstract}

Ключевые слова: моральная философия, этика, поступок, ответственность, М. М. Бахтин.

Научная специальность: 09.00.00 - философские науки. 